\title{
PROFESSIONALISM AND PROTECTION: DISABLED LAWYERS AND ETHICAL PRACTICE
}

\author{
John V. Jacobi
}

Evaluation of attorneys is a difficult task. Law professors, hiring partners, supervising attorneys, judges, and clients all struggle with standards, criteria, and gut instinct. We have to balance the quantity of a lawyer's work against its quality and thoroughness, her effectiveness "on her feet" against her analytic skills as evidenced in extended writing projects, or her mastery of difficult areas of practice against her ability to relate to clients. Our judgment might be clouded by personality clashes, limited evaluative opportunities, competitive feelings, or bias of one sort or another. These uncertainties all arise in the attorney discipline system. In that system, the profession regulates itself, meaning that practicing attorneys evaluate each other. The Model Rules of Professional Conduct ${ }^{1}$ are designed to protect clients and the justice system through the regulation of attorneys primarily by attorneys and not by some outside regulatory force. ${ }^{2}$

This Article examines one aspect of the uncertainty inherent in the attorney discipline system. It argues that the system's evaluative uncertainty is heightened when applied to an attorney with mental illness. People with mental illness are often misunderstood, feared, and subjected to disparate treatment. ${ }^{3}$ The attorney discipline system is not immune from the societal tendency to mistreat people with mental illness through ignorance and fear. ${ }^{4}$ In particular, this Article addresses the difficulties facing attorneys with moderate mental illnesses - those whose mental illness is sufficiently controlled to permit them to practice but sufficiently severe to signal their condition to other attorneys and to affect in some fashion their professional behavior. It asks whether attorneys who are competent but "different" are

\footnotetext{
* $\quad$ Dorothea Dix Professor of Health Law \& Policy, Seton Hall Law School. This paper benefited from comments from participants at the Emory Conference on Ethics and Professionalism, on September 8-9, 2007, at Emory University School of Law.

1. Model Rules of Prof’l Conduct (2007).

2. See infra Part I.

3. See Michael L. Perlin, On “Sanism,” 46 SMU L. Rev. 373, 391 (1992).

4. See generally Stanley S. Herr, Questioning the Questionnaires: Bar Admissions and Candidates with Disabilities, 42 VILl. L. Rev. 635 (1997); Kristy N. Bernard \& Matthew L. Gibson, Professional Misconduct by Mentally Impaired Attorneys: Is There a Better Way to Treat an Old Problem?, 17 GEO. J. LEGAL ETHICS 619 (2004).
} 
sufficiently protected from becoming ensnared in the attorney disciplinary system as a result of the fear or ignorance of their fellow lawyers.

The first part of this Article describes the play in the joints of the attorney discipline system. The standards that require attorneys to perform promptly, competently, and diligently ${ }^{5}$ are subject to extensive commentary, but they remain by necessity quite vague at their borders. An attorney whose mental illness causes him to be regarded as "eccentric" or peculiar is in danger of being perceived as running afoul of those standards while similarly situated attorneys without mental illness might escape attention. The Article then turns to the application of the Americans with Disabilities Act $^{6}$ (ADA) to attorney self-regulation and argues that the very ambiguity of the standards for attorney discipline limits the protections the ADA offers in such cases. It further argues that while the rules for assessing the diligence or competence of a disabled attorney cannot be sharpened, the risks presented by that vagueness can be minimized by creating more specificity in the practice being assessed. That is, while we cannot be more specific about what we mean by "diligent" or "competent" in the abstract, we can work to set practice norms that will more clearly allow differentiation in any particular situation between competent and incompetent practice. The Article next examines the sister profession of medicine and describes a decades-long process of attempting to do just that: apply practice norms to particular aspects of professional practice to allow an assessment of the competence of physicians' particular interventions. The Article encourages the application of the lessons from the medical profession to the law and argues that the sharpening of professional expectations in particular settings can help to shield "eccentric" attorneys from disparate disciplinary attention while potentially providing the side benefit of improving service to clients.

\section{A Dangerous Mix: Vague Professional Ethics Standards and Mental ImPairment}

\section{A. The Functions of the Attorney Discipline System}

The law is a profession, and practitioners are expected to have a level of specialized education, training, and experience that separates them from non-

\footnotetext{
5. See Model Rules of Prof'L Conduct, pmbl., para. 4 ("In all professional functions a lawyer should be competent, prompt, and diligent.").

6. $\quad 42$ U.S.C. $\S \S 12101-12213$ (2000).
} 
lawyers in the practice of their craft. Like members of other professions, lawyers are charged with responsibilities not only to their clients, but by dint of their special expertise and status, to the broader society as well. ${ }^{7}$ The special status of the legal profession carries with it the privilege and responsibility of a large degree of self-governance. ${ }^{8}$ Attorney ethics rules, exemplified today by the American Bar Association's (ABA) Model Rules of Professional Conduct (Model Rules), address all three aspects of this professional status: enforceable standards of professional practice, at least hortatory statements of social obligation, and clearly framed statements of the need for the profession to police itself in order to avoid civil regulatory intrusions.

A primary function of the Model Rules is to set out standards applicable to client representation. They attempt to set out rules that enforce professional norms of competence, client engagement, and hard work. ${ }^{9} \quad$ A competent lawyer must have or obtain the requisite knowledge and skill to perform the required tasks $;^{10}$ he need not come into a representation with the necessary training or experience and can bring himself up to speed during the representation or associate himself with another attorney with the necessary training or experience. ${ }^{11}$ Once undertaking representation, a lawyer must pursue his client's interests with "reasonable diligence and promptness," 12 inform the client of important developments in the representation, consult with the client before taking important actions, and facilitate the client's ability to make important decisions in the course of the representation..$^{13}$ These rules go to the heart of an attorney's responsibilities to her client; they are quite broad and, like common law rules, require interpretation in any particular case.

7. Commission on Professionalism, American Bar Ass’n, “. . . . In the Spirit of Public Service:” A Blueprint for the Rekindling of Lawyer Professionalism 10-11 (1986), http:// www.abanet.org/cpr/professionalism/Stanley_Commission_Report.pdf; see Eugene R. Gaetke, Expecting Too Much and Too Little of Lawyers, 67 U. PITT. L. REv. 693, 698-704 (2006) (discussing professionalism in the context of lawyers' social obligations, and the tension of those obligations with the zealous representation of individual clients).

8. See Model Rules of Prof'L Conduct, pmbl., paras. 10-12. Other sources of regulation are, of course, applicable to attorney practice. Tort law, for example, allows courts to adjudicate common law claims brought by clients against attorneys for incompetent practice. See, e.g., Russo v. Griffin, 510 A.2d 436 (Vt. 1986); Aloy v. Mash, 696 P.2d 656 (Cal. 1985). See generally Restatement (ThiRd) of the LAW Governing LAWYERS (2000) (gathering common law applicable to legal practice).

9. Model Rules of Prof'L Conduct pmbl., para. 4.

10. Id. R. $1.1 \mathrm{cmt} .1$.

11. Id. R. $1.1 \mathrm{cmts} .2,4$.

12. Id. R. 1.3 .

13. Id. R. 1.4. 


\section{B. Interpretation and Application to a Lawyer with Mental Illness}

How do these basic rules apply to an attorney with mental illness? The rules, of course, apply to attorneys with mental illness as they do to any other attorney. ${ }^{14}$ A lawyer with mental illness must act competently and diligently, and he must communicate appropriately with his client and facilitate the client's ability to make decisions central to the prosecution of the matter for which the attorney was retained. As is more fully described below, the generality - even vagueness - of these rules may raise particular concerns for lawyers with mental illness. Other rules have, or might have, particular bite for lawyers with mental illness. Model Rule 1.16, in particular, bars an attorney from undertaking representation where "the lawyer's physical or mental condition materially impairs the lawyer's ability to represent the client." 15

The Model Rules require individual lawyers to conform their conduct to the professional standards set out therein. ${ }^{16}$ The Model Rules, however, also assign to others in the profession responsibility for the supervision of lawyers to prevent misconduct and the reporting of lawyers accused of misconduct. Two rules in particular touch on this professional policing role. First, Rule 5.1 describes the obligation of supervisory attorneys for the conduct of those they supervise. ${ }^{17}$ Supervisory lawyers have an affirmative obligation to operate their firms so as to reasonably assure that "all lawyers in the firm conform to the Rules of Professional Conduct."18 All lawyers have particular responsibility to assure that lawyers under their direct supervision conform their conduct to professional standards. ${ }^{19}$ Supervising lawyers may themselves be disciplined for the misconduct if the supervising attorney, knowing of the other attorney's misconduct, either ratifies the misconduct or

14. See ABA Comm. on Ethics and Prof'1 Responsibility, Formal Op. 429, at 2 (2003) [hereinafter, Formal Opinion 03-429] ("Impaired lawyers have the same obligations under the Model Rules as other lawyers."). This is not to say that other positive law, including disability law, has no part in the application of the rules to lawyers with mental illness. The ADA applies - if the mental illness is disabling - to both the question of whether the attorney's disability can be "accommodated" and to question of whether an attorney with mental illness may use his mental illness as a factor when he argues in mitigation of punishment. See Cincinnati Bar Ass'n v. Komarek, 702 N.E.2d 62, 67-68 (Ohio 1998); Fla. Bar v. Clement, 662 So. 2d 690, 699-700 (Fla. 1995). See infra Part II.

15. Model Rules of Prof'l Conduct R. 1.16(a)(2) (2007).

16. See id. R. 1.1 (“A lawyer shall provide competent representation to a client.").

17. Id. R. 5.1.

18. Id. R. 5.1(a).

19. Id. R. 5.1(b). 
fails to prevent or mitigate the effects of the other lawyer's misconduct. ${ }^{20}$ Rule 5.1, then, sets up incentives for supervising attorneys to be vigilant in looking for signs they interpret as indications that a supervised attorney may be running afoul of the rules, and upon perceiving those signs, to act to limit the supervised attorney's practice.

Rule 8.3 obliges attorneys to report another attorney to "the appropriate professional authority" when they determine that the other attorney's professional conduct "raises a substantial question as to that lawyer's . . . fitness as a lawyer." ${ }^{21}$ The reporting of another attorney is mandatory and applies when the first attorney's knowledge of circumstances raises in his mind "a substantial question" of the other's fitness. This rule sets up incentives for attorneys, including attorneys in adversary positions, to report perceived misconduct to disciplinary authorities.

The operative standards for the engagement of these supervisory or reporting actions are phrased in terms that both are admirable and vague. They are admirable in that they are obviously aimed at protecting clients and the administration of justice. It is appropriate that lawyers themselves be charged with practicing with reasonable competence, diligence, and openness to clients. It is appropriate that supervisory attorneys oversee their subordinates' work so as to reasonably assure competent, diligent, and open practice. And it is appropriate that practitioners who observe misconduct on the part of other attorneys report the misconduct to professional authorities. These steps seem at least minimally responsive to the aspirations of the law to protect clients and to advance social interests in the fair administration of justice.

The standards are also vague. Competence is an appropriate standard for professional practice - indeed, it seems a bare minimum. But what comprises competence? Must an attorney only be as good at researching legal issues as his local peers? Or must his research encompass substantially all relevant law in the field? $?^{22}$ Perhaps, as in many common law areas, indeterminacy of standards is unavoidable given the infinite variety of factual situations to which general rules are applied. ${ }^{23}$ But the generality raises significant concerns for lawyers for two intertwined reasons: (1) society continues to

\footnotetext{
20. Id. R. 5.1(c).

21. Id. R. 8.3(a).

22. See Russo v. Griffin, 510 A.2d 436 (Vt. 1986); Aloy v. Mash, 696 P.2d 656 (Cal. 1985) (raising similar questions in legal malpractice cases).

23. See W. Page Keeton et al., Prosser and Keeton on the Law of Torts $§ 1$, at 6-7 (5th ed. 1984) (describing the multiple factors that go into a determination of "reasonableness" in the law of torts).
} 
misunderstand, fear, and disparately treat people with mental illness; and (2) the structure of the Model Rules places in the hands of individual lawyers the power and ability to either limit the practice of an attorney with mental illness or to initiate the process of professional discipline that may taint his professional reputation.

\section{Bias Against Those with Mental Illness}

Bias against people with mental illness is widespread and appears to be one of the remaining socially acceptable areas of social discrimination. ${ }^{24}$ Notwithstanding increasingly sophisticated clinical research on mental illness that demonstrates that most people with mental illness are entirely capable of participating equally in society, people with mental illness continue to suffer inappropriate and unjustified discrimination in employment, housing, and other basic social goods and services. ${ }^{25}$ In contrast with physical disabilities, it may be that the problem of bias against those with mental disabilities is growing rather than abating with time. ${ }^{26}$

The bias is fed by persistent myths and exaggerations about people with mental illness, including perceptions that they are disproportionately violent, cruel, lazy, and unreliable. ${ }^{27}$ As is true with other biases (or "isms"), ${ }^{28}$ the harm to the subjects of discrimination comes not just from ignorance about mental illness, but from the tendency to evaluate a person according to categories rather than on an individualized basis. This categorical or stereotypic assessment is likely to evaluate any person who is identified as

24. See Elizabeth F. Emens, The Sympathetic Discriminator: Mental Illness, Hedonic Costs, and the ADA, 94 GEO. L.J. 399, 401 (2006):

Treating people differently on the basis of mental illness does not provoke the same moral outrage as that inspired by differential treatment on the basis of race, sex, or even physical disability. Indeed, many people would freely admit preferring someone who does not have a mental illness as a neighbor, dinner party guest, parent, partner, or person on the next seat on Id.

the subway.

25. See Wendy F. Hensel \& Gregory Todd Jones, Bridging the Physical-Mental Gap: An Empirical Look at the Impact of Mental Illness Stigma on ADA Outcomes, 73 Tenn. L. Rev. 47, 51-52 (2005); Michael L. Perlin, “What's Good Is Bad, What's Bad Is Good, You'll Find Out When You Reach The Top, You're On the Bottom": Are the Americans with Disabilities Act (and Olmstead v. L.C.) Anything More Than "Idiot Wind?," 35 U. Mich. J.L. Reform, 235, 238 (2002).

26. See Hensel \& Jones, supra note 25, at 51 (citing Jo C. Phelan et al., Public Conceptions of Mental Illness in 1950 and 1996; What is Mental Illness and is it to be Feared?, 41 J. Health \& Soc. BeHAV. 188, 197-98 (2000)).

27. See Emens, supra note 24, at 416-17; Hensel \& Jones, supra note 25, at 52-56.

28. See Perlin, supra note 25, at 236. 
"mentally ill" according to the evaluator's own view of the capabilities of all persons with mental illness rather than the capabilities of the particular individual with mental illness. ${ }^{29}$ The pervasive bias against people with mental illness, then, tends to result in evaluations rooted in mistaken assessments of mental illness and on mistaken categorical assessments of people with mental illness.

\section{The Power of Individuals over Lawyers with Mental Illness}

The vulnerability of lawyers with mental illness can be highlighted by application of Model Rules 5.1 and 8.3(a). As is described above, Rule 5.1 governs the obligation of supervisory attorneys to assure the ethical practice of supervised attorneys. The ABA published a formal opinion in 2003 advising of the proper application of Rule 5.1 in situations in which the supervised attorney has a mental impairment. ${ }^{30}$ Formal Opinion 03-429 states, in part, "If a lawyer's mental impairment is known to partners in a law firm or a lawyer having direct supervisory authority over the impaired lawyer, steps must be taken that are designed to give reasonable assurance that such impairment will not result in breaches of the Model Rules." 31

Leave aside the question of why there is a formal opinion on the supervision of lawyers with mental impairments and not, say, lawyers with visual or mobility impairments. It might be stated with some plausible neutrality that the ABA Standing Committee on Ethics and Professional Responsibility received more inquiries on the former than the latter. The explanatory text accompanying Formal Opinion 03-429 advises the bar that some apparent mental disorders may not "materially impair" the attorney's ability to practice. ${ }^{32}$ It also cautions the bar that it must be vigilant in its oversight of supervised attorneys with mental impairments:

Unfortunately, the lawyer who suffers from an impairment may be unaware of, or in denial of, the fact that the impairment has affected his ability to represent clients. When the impaired lawyer is unable or unwilling to deal with the consequences of his impairment, the firm's partners and the impaired lawyer's supervisors have an

29. Id.

30. Formal Opinion 03-429, supra note 14.

31. Id. at 1 .

32. Id. at 3 ("[S]ome disorders that may appear to be mental impairment (for example, Tourette's Syndrome), while causing overt conduct that appears highly erratic, may not interfere with competent, diligent legal representation ...."). 
obligation to take steps to assure the impaired lawyer's compliance with the Model Rules. $^{33}$

If proper supervision and appropriate accommodation of the impairment ${ }^{34}$ do not assure the supervisory attorneys that the impaired attorney can practice properly, the lawyer may not render legal services for the firm ${ }^{35}$ and under some circumstances must be reported to proper professional authorities. ${ }^{36}$

If we could assume that the supervisory attorneys are well-versed in the capabilities of people with mental illness, and further that they are free from bias toward people with mental illness, the above advice might not pose significant concerns. But as is described above, bias, mistrust, and misunderstanding of people with mental illness is widespread, and there is no reason to believe that supervisory attorneys are as a class immune to the generally prevailing condition in this regard. The advice contained in Formal Opinion 03-429 could, if applied by attorneys whose judgment is infected by ignorance or bias with regard to mental illness, lead to the inappropriate narrowing of an attorney's practice, his discharge, or to his being reported to disciplinary authorities in circumstances not calling for such intervention.

The ABA Standing Committee on Ethics and Professional Responsibility published another opinion about attorneys with mental impairment. ${ }^{37}$ This opinion concerns the obligations of attorneys to report misconduct by other attorneys who are not under the attorney's supervision. The formal opinion states,

\begin{abstract}
A lawyer who believes that another lawyer's known violations of disciplinary rules raise substantial questions about her fitness to practice must report those violations to the appropriate authority. A lawyer who believes that another lawyer's mental condition materially impairs her ability to represent clients, and who knows that the lawyer continues to do so, must report that lawyer's consequent violation of rule $1.16(\mathrm{a})(2)$, which requires that she withdraw from representation of clients. ${ }^{38}$
\end{abstract}

As an initial matter, the second sentence of this opinion contains a drafting oddity. It begins by positing that a lawyer "believes" that another lawyer's mental condition impairs her ability to represent clients. It then implicitly

33. Id.

34. See id. at 4

35. Id. at 4 .

36. Id. at 5 .

37. ABA Comm. on Ethics and Prof'l Responsibility, Formal Op. 431, at 2 (2003) [hereinafter Formal Opinion 03-431].

38. Id. at 1 . 
states that the first lawyer's belief establishes the second lawyer's violation of Rule 1.16(a)(2). ${ }^{39}$ In addition, however, Formal Opinion 03-431 raises concerns similar to those raised by Formal Opinion 03-429.

The opinion notes that lawyers are not experts in identifying or evaluating mental illness and may consult a mental health professional for assistance, although they are not required to do so. ${ }^{40}$ The opinion explains that an attorney who concludes that another attorney's mental condition impairs her ability to represent clients, whether on the basis of his own unschooled observations ${ }^{41}$ or even on the basis of observations of third parties ("such as a client of the lawyer who complains of the impaired lawyer's conduct"), ${ }^{42}$ is obliged to report the other attorney to appropriate professional authorities. ${ }^{43}$

The concerns raised above regarding Formal Opinion 03-429 apply even more strongly in connection with Formal Opinion 03-431. Against the backdrop of pervasive societal bias, fear, and ignorance regarding people with mental illness, at least the attorneys addressed by Formal Opinion 03-429 have a supervisory relationship with the impaired attorney and the ability to form some common-sense judgments about her capacity to represent clients. Flawed though this assessment might be, it is far preferable to that required by Formal Opinion 03-431, by which an attorney is obliged to report another attorney on the basis of limited contact, possibly through adversarial proceedings, or even on the basis of a complaint from a client of allegedly impaired conduct not witnessed by the reporting attorney. This opinion raises the specter of attorneys obliged against the background of societal ignorance of mental illness to assess another attorney's mental state and capacity to practice on the basis of little or no personal exposure to the other attorney.

The attorney discipline process, then, poses particular problems for attorneys with mental illness. Part II, below, addresses two frameworks within which to evaluate possible means to protect these attorneys from unfair bias in the evaluative process: void-for-vagueness doctrine and disability law.

39. It does no such thing; Rule 1.16(a)(2) requires a withdrawal from representation when a lawyer's mental condition in fact impairs her ability to represent clients. Model Rules of Prof'L Conduct R. 1.16(a)(2) (2007).

40. Formal Opinion 03-431, supra note 37, at 3.

41. Id. at 3-4.

42. Id. at 3 n. 12 .

43. Id. at 4 . 


\section{Vagueness And Disability Law}

\section{A. The Problem of the Wide End of the Funnel}

The preceding section argues that the application of the Model Rules to the evaluation of attorneys who have, or who are believed to have, mental illness threatens those attorneys with biased application of the Model Rules. It argues that imposing the obligation to assess and evaluate the abilities of attorneys believed to have mental impairments on the rank and file of attorneys gives free rein to the pervasive bias against people with mental illness and will likely lead to discrimination against mentally impaired lawyers. The rules do not speak to a cadre of trained investigators, after all, but to fellow practitioners with no special knowledge of either mental illness or the range of legal practice representing the acceptable norm in the jurisdiction.

A response to this argument might be that the rules, and the formal opinions interpreting them, only oblige attorneys to initiate action and leave to the full disciplinary process the evaluation of the bona fides of the claims of impairment. I accept for the sake of the current argument that many reported cases of bar discipline involving people with mental impairments evidence a robust adversary process ${ }^{44}$ whether or not one agrees with the reasoning or the outcome of those cases. ${ }^{45}$ Attorneys with mental illness can take small comfort from the extensive protections provided at the end of the discipline process, however, for two reasons. First, the application of Rule 8.1 and Formal Opinion 03-429 lead not to discipline, but to an obligation to "prevent the attorney from rendering legal services to clients of the firm." 46 This action would not in itself lead to any further process unless the affected attorney were to pursue a claim of employment discrimination. Second, and more significant for purposes of this Article, the initiation of discipline is in itself a harm to an attorney with a mental impairment, and if the disciplinary process were to lead to a systematic bias even in the initiation of proceedings, the process would be infected with discriminatory bias. The significance of

44. See Cincinnati Bar Ass'n v. Komarek, 702 N.E.2d 62, 67-68 (Ohio Ct. App. 1998); Fla. Bar v. Clement, 662 So. 2d 690, 699-700 (Fla. 1995).

45. See Robert Dowers, Duties Invoked Under the Model Rules of Professional Conduct by a Mentally Impaired Lawyer, 19 Geo. J. Legal Ethics 681 (2006); Bernard \& Gibson, supra note 4; Christopher D. Kratovil, Note, Separating Disability from Discipline, 78 TEx. L. Rev. 993 (2000).

46. Formal Opinion 03-429, supra note 14, at 4. 
this bias in the initiation of discipline is highlighted by first describing the nature of the early part of the disciplinary process, and then by describing the problem of employing vague standards in such a process.

\section{The Burden of Defending a Disciplinary Matter}

Attorneys, like all professionals, have an interest in their professional reputation and, like all persons, a preference for avoiding inaccurate claims of impairment and incapacity. The attorney's ultimate vindication is of limited solace if his reputation has been harmed by accusations of unethical conduct and, in particular, by claims of incapacity due to mental impairment. ${ }^{47}$

In New Jersey, attorney ethics complaints received from all sources are received by a District Ethics Committee, comprised of attorneys practicing in the committee's geographic district. ${ }^{48}$ If the attorney-secretary of that committee does not dismiss the matter initially, it is investigated, sometimes by another attorney-member of the committee. ${ }^{49}$ If the attorney-chair of the committee determines after investigation that there is a "reasonable prospect of a finding of unethical conduct by clear and convincing evidence," attorney-director authorizes the filing of a complaint against the subject attorney. ${ }^{51}$

From the time the complaint is filed, the documents and proceedings are open to the public, ${ }^{52}$ including the initial hearing, the administrative hearing on appeal, and any subsequent court review. The process for the affected attorney can involve public disclosure of a complaint alleging unethical conduct, a public hearing before a panel comprising two attorneys and one lay member, ${ }^{53}$ review of the decision by a statewide disciplinary review board comprising an attorney and lay member, ${ }^{54}$ and review of the final

47. The inadequacy of ultimate vindication in restoring one's personal and professional reputation is captured by the question asked by Raymond Donovan, Secretary of Labor under President Ronald Reagan, upon being acquitted at trial for fraud: "Which office do I go to to get my reputation back?" See USAToday.com; 25 Most Memorable Quotes, http://www.usatoday.com/news/top25-quotes.htm (last visited Aug. 15, 2008).

48. N.J. Ct. R. 1:20-3(e).

49. Id. R. 1:20-3(g).

50. Id. R. 1:20-3(i)(1).

51. Id. R. 1:20-3(i)(3).

52. Id. R. 1:20-9(c). There is an exception for proceedings where disability is alleged. Id. R. $1: 20-9(f)$.

53. Id. R. 1:20-6(a)(1).

54. Id. R. 1:20-15(a). 
administration decision by the New Jersey Supreme Court. ${ }^{55}$ These proceedings, most of which are open to the public, can impose significant burdens on attorneys even if they ultimately prevail.

\section{Vagueness}

Our tolerance for the possibility that a person will be harmed by being subjected to a burdensome process such as that described in the previous section depends in large part on our confidence that the imposition of the burden is governed by reasonable criteria. There are two significant concerns regarding the guidance provided by the Model Rules and the formal opinions as they apply to lawyers with mental illness. The first is the possibility that the treatment of attorneys with mental illness is discriminatory in violation of the ADA. That issue is taken up in Part II(B) below. The second, taken up in this section, is that the standards are inappropriately vague.

The void-for-vagueness doctrine has been employed to invalidate criminal laws that are insufficiently clear in describing the nature of the conduct prohibited. ${ }^{56}$ It has been used to invalidate an ordinance permitting the arrest of persons who do not disperse when ordered to do so by the police ${ }^{57}$ and antiloitering laws that criminalize being in a public place without an adequate purpose. $^{58}$ The justification for the void-for-vagueness doctrine is twofold. First, due process requires that the state inform people of the nature of the conduct that can subject them to punishment. Second, however, vague laws give agents of the state inappropriate discretion to choose to whom to apply the law, empowering law enforcement to use criminal laws for narrow, perhaps personal purposes rather than the broad public purposes for which the laws were created. ${ }^{59}$

The void-for-vagueness doctrine likely does not apply in the attorney discipline context. Outside of the First Amendment context it ordinarily applies only to criminal laws, and attorney discipline matters are administrative, quasi-judicial proceedings. ${ }^{60}$ The reasoning of the Supreme Court's vagueness cases has some force in this context, however. When the

55. Id. R. 1:20-16(a), (b).

56. The void-for-vagueness doctrine has also been used to strike laws that limit free speech. The Court has held that speech rights require "breathing room," and that vague laws may inhibit full expression. See NAACP v. Button, 371 U.S. 415, 432-33 (1963).

57. City of Chicago v. Morales, 527 U.S. 41 (1999).

58. Kolender v. Lawson, 461 U.S. 352 (1983); Papachristou v. Jacksonville, 405 U.S. 156 (1972).

59. See Kolender, 461 U.S. at 358.

60. See Fla. Bar v. Clement, 662 So. 2d 690, 698 (Fla. 1995). 
vague standards of conduct - diligence, competence, openness - are applied in the context of attorneys believed to have mental impairments, the concerns match closely those recognized by the Court in City of Chicago v. Morales, Kolender v. Lawson, and Papachristou v. Jacksonville. ${ }^{61}$ First, the breadth of the standards creates substantial difficulties in deciding, in close cases, on which side of the line a particular attorney's conduct falls. Second, the pervasive societal bias against people with mental illness, coupled with the informality of the process by which disciplinary action can be initiated, raises concerns about diversion of the process from broad client-protection goals to targeting of disfavored groups of attorneys with mental impairments.

The void-for-vagueness doctrine does not itself provide a legal lever for challenging the validity of the attorney ethics process as applied to attorneys with mental illness. It highlights, however, the seriousness of the problems created when fellow attorneys, inexpert in the identification and evaluation of mental illness, are charged with overseeing the practice of other attorneys who have, or are suspected of having, some form of mental impairment. The next section examines the application of disability law to this problem.

\section{B. The ADA: Good Intentions, No Remedy}

The passage of the ADA raised hopes that the sorts of fear, bias, and stigma faced by lawyers with mental illness would cease improperly interfering with their ability to practice. It was to be an "Emancipation Proclamation" for people with disabilities ${ }^{62}$ — the signal for a "bright new era of equality, independence, and freedom.." ${ }^{33}$ The reasons for the failure of the ADA to live up to its billing generally, ${ }^{64}$ and in the case of people with mental impairments specifically, ${ }^{65}$ are addressed comprehensively elsewhere, and will

61. See supra notes 57-58.

62. See 136 Cong. Rec. S9529 (daily ed. July 11, 1990) (statement of Sen. Harkin); 135 Cong. REC. S10789 (daily ed. Sept. 7, 1989) (statement of Sen. Kennedy).

63. President George H.W. Bush, Remarks on Signing the Americans with Disabilities Act of 1990, 2 Pub. PAPers 1067, 1068 (1991).

64. See generally Kelly Cahill Timmons, Disability Related Misconduct and the Legal Profession, 69 U. Pitt. L. Rev. 609 (2008); James Leonard, The Equity Trap: How Reliance on Traditional Civil Rights Concepts Has Rendered Title I of the ADA Ineffective, 56 CASE W. RES. L. REV. 1 (2005); Ruth Colker, Winning and Losing Under the Americans with Disabilities Act, 62 Оноо Sт. L.J. 239 (2001).

65. See generally Emens, supra note 24; Jeffrey Swanson et al., Justice Disparities: Does the ADA Enforcement System Treat People with Psychiatric Disabilities Fairly?, 66 MD. L. REv. 94 (2006); Hensel \& Jones, supra note 25; Jane Byeff Korn, Crazy (Mental Illness Under the ADA), 36 U. Mich. J.L. Reform 585 (2003); Suan Stefan, Delusion of Rights: Americans with Psychiatric Disabilities, Employment Discrimination, and the Americans with Disabilities Act, 52 ALA. L. Rev. 271 (2000); Stephanie Proctor 
only be sketched out here. In brief, the courts' interpretation of the ADA has blocked the way for attorneys seeking its protection in the course of attorney discipline proceedings. The blocking issues briefly discussed below suggest that (1) the attorney may not be "disabled" enough to claim the ADA's protection, and (2) the attorney may be too disabled to be "qualified" for the task of practicing law.

\section{Disability}

Attorneys with psychiatric impairments may face discrimination in the application of Model Rule 5.1, when a law firm restricts the lawyer's practice or discharges him from the firm, ${ }^{66}$ and under Model Rule 8.1(a), when another lawyer reports him to disciplinary authorities on the basis of his psychiatric impairment. ${ }^{67}$ A person is "disabled" under the ADA if she has an impairment that substantially limits her engagement of major life activities. ${ }^{68}$ The range of interpretations of this definition has been sharply constrained by the courts. For example, having monocular vision does not "significantly limit" the activity of seeing. ${ }^{69}$ Very limited sight is not (currently) "significantly limiting" if it can be corrected with glasses. ${ }^{70}$ And even a devastating loss of function is not disabling if that function is not of "central importance to daily life." ${ }^{71}$

Lawyers with mental impairments are likely to be caught in one of these screens and be determined not "disabled," and therefore unable to pursue a claim under the ADA. They will, after all, have succeeded in finishing law school and gaining admission to the bar-how disabled can they be? If their disability is framed as social awkwardness, or limitations in the ability to "get along" with coworkers or other attorneys, they will face several hurdles. It may be that their psychiatric symptoms are "correctable" with medication, in

Miller, Comment, Keeping the Promise: The ADA and Employment Discrimination on the Basis of Psychiatric Disability, 85 CAL. L. REv. 701 (1997).

66. The ADA prohibits discrimination on the basis of disability in the terms and conditions of employment. See 42 U.S.C. § 12112 (2000)

67. The ADA prohibits disparate treatment in participation in public services, programs, or activities (such as the attorney ethics system) on the basis of disability. See id. § 12132.

68. Id. $\S 12102(2)(\mathrm{A})$. The ADA also protects people who are "perceived" to have a disability, or who have a "record" of a disability. Id. $\S 12102(2)(\mathrm{B})-(\mathrm{C})$.

69. See Albertson's, Inc. v. Kirkingburg, 527 U.S. 555, 565-66 (1999).

70. See Sutton v. United Air Lines, Inc., 527 U.S. 471, $483-87$ (1999).

71. Toyota Motor Mfg., Ky. v. Williams, 534 U.S. 184, 191 (2002). 
which case they are not disabled. ${ }^{72}$ It may be that a court will decide that the ability to interact with others is not a "major life activity." "3 Other courts may consider, in light of the attorney's ability to gain his current place in society, that his impairment is insufficiently severe to be disabling. ${ }^{74}$ The ADA, then, offers a shrinking definition of disability.

\section{Qualification}

If the attorney is able to establish that she is disabled for purposes of the ADA, she must then establish that she is "qualified" to act as an attorney notwithstanding her disability. The employment title of the ADA requires a plaintiff to demonstrate that she is able to perform the essential functions of the job with reasonable accommodation. ${ }^{75}$ The employer's assessment of which aspects of the job are "essential" is entitled to deference. ${ }^{76}$ The public services title of the ADA (applicable to the state machinery of attorney discipline $)^{77}$ requires that the attorney meet the "essential eligibility requirements" of the program with accommodation. ${ }^{78}$ It is likely that an attorney determined by her peers to have violated the rules of ethical practice because of her mental impairment ${ }^{79}$ will have difficulty establishing that she is "qualified" to act as an attorney under either standard. ${ }^{80}$

Courts have historically deferred to professional authority figures in disability cases. ${ }^{81}$ In attorney discipline cases, courts have been deferential to discipline authorities. In Florida Barv. Clement, ${ }^{82}$ the Florida Supreme Court disbarred an attorney with bipolar disorder. It found that it would defer to the factual findings of the Florida Bar's referee in the case. ${ }^{83}$ It therefore found

72. See Sutton, 527 U.S. at $483-87$.

73. Compare Davis v. Univ. of N.C., 263 F.3d 95, 101 (4th Cir. 2001) (it is not), with McAlindin v. County of San Diego, 192 F.3d 1226, 1234 (9th Cir. 1999) (it is).

74. See Rohan v. Network Presentations LLC, 375 F.3d 266 (4th Cir. 2004) (posttraumatic stress disorder). See generally Judith J. Johnson, Rescue the Americans with Disabilities Act from Restrictive Interpretations: Alcoholism as an Illustration, 27 N. ILL. U. L. REV. 169, 187-205 (2007).

75. 42 U.S.C. $§ 12111(8)(2000)$.

76. $I d$.

77. See Okla. Bar Ass'n v. Busch, 919 P.2d 1114, 1118 (Okla. 1996).

78. $§ 12111(8)$

79. See Formal Opinion 03-429, supra note 14, at 1.

80. Subject, of course, to the accommodation requirement.

81. See, e.g., McGregor v. La. State Univ. Bd. of Supervisors, 3 F.3d 850, 859 (5th Cir. 1993) (structure of law school curriculum); Amir v. St. Louis Univ., 184 F.3d 1017, 1028 (8th Cir. 1999) (medical school qualifications).

82. 662 So. 2 d 690 (Fla. 1995)

83. Id. at 696 . 
that the attorney's bipolar disorder did not have a causal relationship with the attorney's commission of misconduct. ${ }^{84}$ Significantly, the court found in the alternative that, even if a causal connection were shown, it would be required to determine whether the attorney's mental condition would lead to misconduct in the future. ${ }^{85}$

The strong implication of Clement is that the bar's assessment of an attorney's qualification to practice law ethically will guide courts in discipline cases. This implication follows in part from the deference the court showed to the bar's fact-finding process. ${ }^{86}$ In addition, however, it follows from the shared interest of the bar and the courts to shore up the social reputation of lawyers and the justice system. In Oklahoma Bar Association v. Busch, ${ }^{87}$ the Oklahoma Supreme Court described this strong interest in affirming the discipline of an attorney with a mental impairment: "We would be shirking our duty as the guardians of the state's bar were we to permit [r] espondent to avoid discipline. Such would surely erode public confidence in the bar." 88 Nor is such concern unreasonable. In both Clement and Busch, the courts found compelling evidence of conduct harmful to clients and the administration of justice, and little or no evidence that accommodation of the attorneys' impairments would have permitted that harm to be avoided.

But how does the message of these cases filter down to the large end of the funnel in the disciplinary process? Formal Opinion 03-429 asks supervisory attorneys to assess an attorney's mental impairment and to act so as to prevent future ethical breaches. ${ }^{89}$ Similarly, Formal Opinion 03-431 requires an attorney who "believes that another lawyer's mental condition materially impairs her ability to represent clients" to report that attorney to disciplinary authorities. ${ }^{90}$ In both situations, attorneys are asked to forecast future attorney misconduct on the basis of their unschooled assessment of the attorney's impairment. The bar's strong preference for client protection, as evidenced by Clement and Busch, is likely to encourage attorneys to over-read other attorneys' impairments. The justifications of this over-reading would be, first, that the protection of clients and the bar is the central reference point

84. Id. at 700 .

85. Id.; see Timmons, supra note 64, at 612-14 (discussing alternative holding of Clement).

86. See Clement, 662 So. $2 \mathrm{~d}$ at 696.

87. 919 P.2d 1114 (Okla. 1996).

88. Id. at 1120 .

89. Formal Opinion 03-429, supra note 14, at 1 ("If a lawyer's mental impairment is known to partners in a law firm ...., steps must be taken that are designed to give reasonable assurance that such impairment will not result in breaches of the Model Rules.").

90. Formal Opinion 03-431, supra note 37, at 1 . 
in attorney discipline cases, and second, that any ADA-based excuses or mitigation can be addressed during the adjudication process pursuant to Clement's articulation of case-by-case assessment of disability evidence. ${ }^{91}$

The ADA, then, is likely to be formally unavailable to mentally impaired attorneys enmeshed in the attorney discipline process because they are either not disabled, or because their mental impairment renders them unqualified to practice law, or both. But the philosophy of disability law goes beyond that formal bar. In the low-level cases of concern in this Article, the message attorneys will receive is that, first, the ADA applies only to exotically disabling conditions and not to the eccentricities of fellow attorneys, and second, that to the extent real disabilities emerge as the explanation for ethical misconduct, the interest of the bar in protecting clients and the administration of justice will trump disability law's protection of the attorney. These lessons will mesh nicely with the social biases and fears to which attorneys are subject, leaving the attorney with a psychiatric disability both more likely to be ensnared in the discipline process and without an easy remedy for freeing herself.

\section{Specificity of Legal Practice: Addressing the Context, Not THE CONDUCT}

Part II argued that (1) attorneys with mental impairments are governed by disciplinary rules and opinions that subject them to vague standards of conduct; (2) the social biases that infect the treatment of people with mental illness are likely to skew the application of these vague standards to their detriment at the "large end of the funnel" - that is, at the initiation and early stages of the disciplinary process; and (3) neither the void-for-vagueness doctrine nor the ADA are likely to be of much use in correcting this skewing. Implicit in the foregoing argument is that the vague standards of ethical practice are not easily subject to substantial refinement because they must apply to a multiplicity of factual circumstances. ${ }^{92}$ The identified danger therefore remains: Attorneys with psychiatric impairments that are apparent to other attorneys will be subject disproportionately and (in many cases) incorrectly to the reporting and adjudication process of the attorney ethics system.

91. See Clement, 662 So. $2 \mathrm{~d}$ at 700 .

92. See supra text accompanying notes 16-22. 
This Part takes as given that the standards of ethical practice are and will remain vague. It suggests, however, that attorneys with mental disabilities can benefit from an attempt to approach the problem from, as it were, the other direction. What if we left the standards (e.g., diligence, competence, zeal) as they are, and attempted to specify more carefully what it is to practice well? This endeavor is aided by the fact that a sister profession-medicine-has embarked on just such a venture. As is the case with the law, the standards for the practice of medicine have tended to be quite general and committed to the discretion of each practitioner. In the last several decades, however, researchers have examined the practice of medicine in order to do two things: first, they have looked for unexplained variation in practice; second, they have looked to determine whether patients are harmed or costs are affected by such variation.

The following section briefly describes the extensive literature of small area variations in medical practice and the normative and regulatory response. That response is an attempt to reduce the range of variation in order to avoid patient harm. The subsequent and final section considers whether a cognate effort in the law can both protect patients from harm and, incidentally, protect disfavored attorney groups, such as those with psychiatric impairment, from disparate professional sanction.

\section{A. Small Area Variation in Medical Care}

John Wennberg and other researchers associated with Dartmouth Medical School have been studying variation in physician practice for over three decades. ${ }^{93}$ This brief discussion can do no more than provide an overview of a technically complex, voluminous body of work. Wennberg's fundamental insights are that variations in physician practice exist and are not explained by professionally valid factors. Further, this variation at least potentially subjects patients to harm and increases the cost of care. As he described in 1984:

Most people view the medical care they receive as a necessity provided by doctors who adhere to scientific norms based on previously untested and proven treatments. When the contents of the medical care "black box" are examined more closely, however, the type of medical service provided is often found to be as strongly influenced by subjective factors related to the attitudes of individual physicians as by science. These subjective considerations, which I call collectively the "practice

93. John E. Wennberg, Dealing With Medical Practice Variations: A Proposal for Action, Health AfFAIRS, Summer 1984, at 7, available at http://content.healthaffairs.org/cgi/reprint/3/2/6.pdf (gathering prior articles). 
style factor," can play a decisive role in determining what specific services are provided a given patient as well as whether the treatment occurs in the ambulatory or inpatient setting. As a consequence, this style factor has profound implications for the patient and payer of care. ${ }^{94}$

These unjustified practice variations are ubiquitous, having been identified in the United States, Canada, Europe, and Australia. ${ }^{95}$

One practice area in which variation has been studied is the treatment of acute myocardial infarction (heart attack). In a study of 186,800 patients who had suffered acute myocardial infarction, researchers found substantial variation in care in areas in which, significantly, there are well-understood, scientifically valid practice standards. ${ }^{96}$ Over 17,000 patients in the study were determined to have been "ideal" candidates for reperfusion therapy. ${ }^{97}$ The mean rate of providing this therapy to this ideal cohort was only $67.2 \%$. More tellingly, the variation was extreme from region to region, with a rate at the 20 th percentile of only $33 \%$, and a rate at the 80 th percentile of over $93 \%$. At the 20th percentile, then, only $33 \%$ of ideal candidates for a wellunderstood intervention received it. ${ }^{98}$

The same study examined the rate at which patients judged ideal candidates for the prescription of beta-blocking agents received those agents at hospital discharge. ${ }^{99}$ Less than half of the patients judged ideal for this therapy received the prescriptions; at the 20th percentile no patients received the prescription, while at the 80 th percentile almost $93 \%$ did. ${ }^{100}$ Again, this therapy was well-understood to be the proper course of treatment for the patients identified, and the failure to provide the therapy was not found to be justified by any medical factor.

Several studies of the provision of care to patients with chronic illness and to patients at the end of life demonstrate similar unexplained variation. In a large study of care for patients with identified chronic illnesses in the last two years of life in California hospitals, researchers found wide variation in the cost of care, with the higher cost care not associated with any superiority

94. Id.

95. John E. Wennberg, Editorial: Understanding Geographic Variation in Health Care Delivery, 340 New Eng. J. Med. 52, 52 (1999).

96. Gerald T. O'Connor et al., Geographic Variation in the Treatment of Acute Myocardial Infarction: The Cooperative Cardiovascular Project, 281 J. Am. Med. Ass'N 627, 627 (1999).

97. Id. at 631 ("Reperfusion includes treatment with thrombolytic agents or primary percutaneous transluminal coronary angioplasty during the first 12 hours after hospitalization.”).

98. $\quad I d$.

99. Id.

100. $I d$. 
in treatment. ${ }^{101}$ A similar study of seventy-seven well-known American hospitals found similar wide variation in care in the last six months of life of patients with identified chronic illness. The variations were significant, unrelated to quality of care, and consistent by providers over time. ${ }^{102}$

These and other studies demonstrate that there is wide, unjustified variation in physician practice both from region to region and within regions for a large number of procedures. ${ }^{103}$ Even after over three decades of study, researchers have only scratched the surface of the data, and further studies in new practice areas will continue to be done. ${ }^{104}$ What policy messages can be discerned from this troubling body of research? Wennberg suggests three steps toward a remedy for this unwarranted variation. First, he argues for a refocusing of medical research from its single-minded attention to new modalities of effective care to the evaluation of unwarranted variation in care as to which physicians have discretion. ${ }^{105}$ Second, he recommends that physicians be provided with financial incentives to conform their practice behavior in particular care settings to those interventions proven to be most effective. ${ }^{106}$ Third, he recommends that national scientific research bodies turn their focus to the "systematic evaluation of the everyday practices of medicine." ${ }^{107}$ Others similarly interpret this data as calling for more research to identify best practices in medicine, to publishing the results of such research widely, and to create improved incentives to incline physicians to follow these best practices. ${ }^{108}$

Medicine, then, has produced substantial evidence that relying on physicians' professionalism to practice effectively is a mistaken strategy. Rather, difficult and detailed research has been undertaken to uncover substantial unwarranted variations in practice. These data have spurred interest in abandoning the practice of relying on the ungoverned judgment of

101. John E. Wennberg et al., Evaluating the Efficiency of California Providers In Caring For Patients With Chronic Illness, HeAlth AfFairs, Nov. 16, 2005, at W5-526, 530.

102. John E. Wennberg et al., Use of Medicare Claims Data To Monitor Provider-Specific Performance Among Patients With Severe Chronic Illness, Health Affairs, Oct. 7, 2004, at VAR-5, 8-11, available at http://content.healthaffairs.org/cgi/reprint/hlthaff.var.5v.

103. Wennberg, supra note 93 , at 52.

104. Id.

105. John E. Wennberg, Perspective: Practice Variations And Health Care Reform: Connecting The Dots, Health Affairs, Oct. 7, 2004, at VAR-140, 143, available at http://content.healthaffairs.org/ cgi/reprint/hlthaff.var.140v1.

106. Id.

107. Id.

108. Earl P. Steinberg, Improving the Quality of Care: Can We Practice What We Preach?, $348 \mathrm{NEW}$ ENG. J. MED. 2681, 2681-82 (2003). 
practitioners for quality care and have generated efforts to identify and publicize best practices across a wide range of physician interventions. The next section suggests an application of this development to the practice of law.

\section{B. Reducing Variation in Legal Practice}

Wennberg and his colleagues' studies have pushed medicine to examine its assumptions of the autonomy of physician judgment, the exercise of which has been shown to result in variations that are dangerous to patients and costly to payers. The response to these studies has been calls to reduce ungoverned physician autonomy with the goal of producing more uniform practice. The task will be difficult; it is not, after all, directed toward broad concepts of competence or diligence but to specific choices of interventions in particular care settings.

There is no Wennberg of the law. The adoption of Wennberg's passion by the legal profession, however, could result in better understanding of the level of unwarranted variation in the practice of medicine. Assuming that there is variation in law approaching that which Wennberg has revealed in medicine (a safe assumption), the application of remedies cognate to those suggested for medicine should produce similar remedies: improved service to clients at a reduced cost. But those goals are off the point of this Article. More to the point, I suggest that a Wennberg-like approach - identifying and eliminating unwarranted variations in legal practice - can improve the lot of attorneys with mental disabilities.

To recap, the problem I have suggested is that attorneys with mental disabilities face the large end of the legal disciplinary system's funnel. The orientation of the Model Rules and the formal opinions, combined with societal misunderstanding and distrust of people with psychiatric impairments, are likely to result in many attorneys swept into the disciplinary system because other attorneys make the generalized judgment that the impaired attorney is likely to be unable to ethically represent clients. I say that this judgment will be "generalized" because it is, as is more fully described above, likely to be based on a prediction of future unethical practice based on a style of practice observed by the attorney in the past.

But on what will the reporting attorney base this judgment? There are few "best practices" in the law. There is little research on the degree of preparation an attorney must undertake before the first meeting in a large transaction. There is no study of the proper length of time and amount of billing appropriate for the securing of a particular regulatory permit or license. There is little formal analysis of the amount of pretrial factual investigation 
that is appropriate for a minor felony trial. No benchmarks exist for the degree of creativity in research into secondary sources that is appropriate for an appellate brief in an antitrust matter. Attorneys considering the propriety of another's practice style are likely, therefore, to make their assessments on the basis of their ungoverned judgment - their gut.

If Wennberg's three decades of research stands for anything, however, it is for the proposition that, in the case of physicians, the ungoverned judgment is a chancy, dangerous thing, as likely to misperceive best practices as to adopt them. Wennberg's work has established that medicine should try its best to supersede judgments based on reified physician autonomy and instead identify best practices and hold physicians to them. If (as is likely) the practice of law is as shot-through with unwarranted variation as is the practice of medicine, then we should be very leery of allowing individual attorneys to apply their idiosyncratic judgments of proper practice in any practice setting to the practice style of any other attorney-let alone one who is likely to invoke fear and misunderstanding in the evaluating attorney.

\section{CONCLUSION}

The attorney discipline system contains a series of potential traps for attorneys with psychiatric illness, including those at the "wide end of the funnel," where initial contact with the system occurs. Societal bias and misunderstanding of those with mental illness is likely to infect this system, and disability law is unlikely to provide effective remedies. Their plight cannot be remedied by more carefully crafting the standards for ethical practice; as with tort law, these general standards may be the best we can do. To protect these attorneys (and, incidentally, to protect clients as well) law should borrow from medicine. Medicine has adhered to its general requirements of medical practice but has undertaken to identify, on a procedure-by-procedure basis, best practices for physicians. This effort follows the discovery that physicians, left to their own devices, vary wildly in their styles of practice. There is no reason to believe that the practice of law has less harmful practice variation than does medicine. The attempt to follow medicine's lead to identify good — or best — practices in a variety of settings will protect clients. It may also provide benchmarks that are better for assessing the practice styles of attorneys than the gut of their fellows, thereby squeezing out some of the opportunity for discriminatory ensnarement of attorneys with mental illness in the discipline system. 